OPEN ACCESS

Edited by:

Ugo Cioffi,

University of Milan, Italy

Reviewed by:

Ryoung Choi,

Dongshin University, South Korea Yanfang Su,

University of Washington,

United States

*Correspondence:

Tao-Hsin Tung

ch2876@yeah.net

Ching-Wen Chien

ihhca@sz.tsinghua.edu.tw

Specialty section:

This article was submitted to

Family Medicine and Primary Care,

a section of the journal

Frontiers in Medicine

Received: 16 October 2020

Accepted: 18 June 2021

Published: 22 July 2021

Citation:

Liu W-Y, Hsu C-H, Liu T-J, Chen P-E,

Zheng B, Chien C-W and Tung T-H (2021) Systematic Review of the Effect of a Zero-Markup Policy for Essential

Drugs on Healthcare Costs and Utilization in China, 2015-2021.

Front. Med. 8:618046.

doi: 10.3389/fmed.2021.618046

\section{Systematic Review of the Effect of a Zero-Markup Policy for Essential Drugs on Healthcare Costs and Utilization in China, 2015-2021}

\author{
Wen-Yi Liu ${ }^{1,2,3}$, Chia-Hsien Hsu', Ting-Jun Liu' ${ }^{5}$, Pei-En Chen ${ }^{6}$, Boyuan Zheng ${ }^{2}$, \\ Ching-Wen Chien ${ }^{2 *}$ and Tao-Hsin Tung ${ }^{7 *}$
}

${ }^{1}$ Department of Health Policy Management, Bloomberg School of Public Health, Johns Hopkins University, Baltimore, MD, United States, ${ }^{2}$ Institute for Hospital Management, Tsing Hua University, Shenzhen, China, ${ }^{3}$ Shanghai Bluecross Medical Science Institute, Shanghai, China, ${ }^{4}$ Department of Public Health, College of Health Science, Kaohsiung Medical University, Kaohsiung, China, ${ }^{5}$ Tai Kang Institute of Healthcare Management, Beijing, China, ${ }^{6}$ Institute of Health Policy and Management, College of Public Health, National Taiwan University, Taipei, Taiwan, ${ }^{7}$ Evidence-Based Medicine Center, Taizhou Hospital of Zhejiang Province Affiliated to Wenzhou Medical University, Linhai, China

Objective: This systematic review aimed to discuss the effects of a zero-markup policy for essential drugs (ZPED) on healthcare costs and utilization in China in the years 2015-2021.

Methods: We searched the PubMed, Embase, Scopus, and CINAHL databases for all associated studies carried out from January 1, 2015, to May 31, 2021, without any limitations regarding the language the studies were written in. To prevent selection bias, gray documents were tackled by other means. The methodological approaches were assessed by applying the Preferred Reporting Items for Systematic Reviews and Meta-Analyses (PRISMA) guidelines and the Newcastle-Ottawa Scale (NOS) collaboration tool.

Results: Forty studies were selected at first and then 15 studies that met the inclusion criterion. Most of the studies showed a considerable decrease in total medical spending and drug spending in both outpatient and inpatient services. After the implementation of ZPED, studies showed that the medical services increased and total hospital income sustained, despite a decrease in drug revenue. Minimal or no government subsidy is required from a financial perspective.

Conclusions: Although, the government could implement ZEPD with lower medical cost and drug cost to patients, and sustained income for health facilities, we have limited understanding of whether the increase in medical services was induced by the provider or was a response to unmet needs in the population. Further, studies using rigorous and advanced methods to study health policy, patient behaviors, provider behaviors, and government decisions are warranted.

Keywords: zero-markup policy, medical expenditure, systematic review, China, healthcare 


\section{INTRODUCTION}

The Policy on Drug Markups (PoDM) implemented by the government in 1954 allowed medical institutions in China to increase drug prices by a maximum of 15\% (1). From the 1980's, it became evident that patients were struggling with obtaining medical care due to the insufficient fiscal allowance and increases in drug costs (2). The Chinese government launched a campaign of clinical health modernization to mitigate these problems and implemented the zero-markup policy for essential drugs (ZPED) in 2009. The ZPED mandated that the markup from medication bills could no longer be retained and that $10 \%$ of the original $15 \%$ markup under the PoDM would be substituted by fiscal allowance. The answer for the remainder of the discharge was believed to be a preposterous method, and it was thought that diagnostic expenses would be increased to obtain $80 \%$ of the former markup. The others were the main parts of the hospitals themselves (3).

Even though the implementation of ZPED was essential to restrict the increase in drug prices, it could not prevent patients from experiencing financial difficulties, which are now caused by paying for other treatments rather than expensive drugs. For instance, when the policy was initially implemented (2009-2011), the pharmaceutical fees of patients per visit were decreased, particularly in rural areas and counties. An evidencebased study showed that the substitution effect of medical consumables offsets the decrease in total expenditure in the long term (4). Hospitals that rely on earnings by drugs to cover their costs could be mitigated by ZPED (5). From 2011 to 2015 , this strategy was no longer a pilot scheme and came to be used in all county-level hospitals in China. However, medical expenses were still rising, in spite of efforts to control the increase (2). This meant that hospitals were able to increase their spending on other medical areas covered by ZPED, such as discharge diagnosis fees, nursing payments, surgery expenses, and treatment fees (2).

Most previous studies on this topic focused on the enduring effects of ZPED on expenses of patients per visit, in particular, drug costs, but neglected the overall cost of the process of therapy. Therefore, this systematic review aimed to discuss the effects of ZPED on healthcare costs and utilization in China from 2015 to 2021 .

\section{MATERIALS AND METHODS}

\section{Data Sources and Selection}

We searched the PubMed, Embase, Scopus, and CINAHL databases for all associated studies carried out from January 1, 2015, to May 31, 2021, without any limitations regarding the language the studies were written in. To prevent selection bias, gray documents-for example, OpenGrey and Open Access Theses and Dissertations-were tackled by other means. We performed a search of the aforementioned electronic databases, applying keywords included in the title and/or abstract as follows: ("pharmaceutical*” OR "drug*” OR "medicine*”) AND [("zero") AND ("markup" OR "mark-up") AND ("China")]. The selection sheets of the associated studies were evaluated
TABLE 1 | Search strategy in PubMed up until 31th May 2021 (similar search run in other databases).

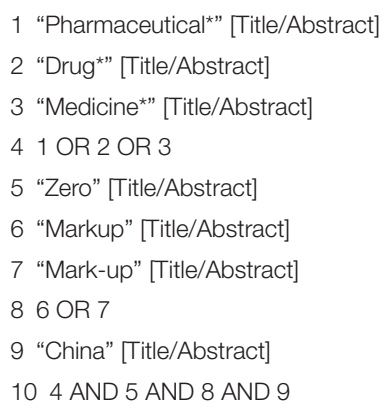

manually to identify comparable works (Table 1). Due to the fact that no study patients were enrolled, as we only used published studies, it was not necessary for us to obtain approval from the institutional review board (IRB) for this systematic review. Two reviewers evaluated regular studies that assessed the effects of ZEPD on the annual medical expenditure per subject and the expense of courses of therapy. Disagreements were resolved via conversation with a well-trained third reviewer. The studies we selected were original articles rather than letters to the editor, editorials, commentaries, or congress documents. The results of these included investigations should be related to the financial indicators of medical institutions. For instance, we aimed to find data on the total expense per inpatient or outpatient visit, the costs of drugs per visit, the number of visits a patient required, etc.,

\section{Data Extraction and Quality Assessment}

The Newcastle-Ottawa Scale (NOS) was used for quality assessment (6). This is an approach that has been proven to be effective for appraising methodological quality in non-randomized controlled trials. The two reviewers also summarized the relevant features of the selected studies using a standardized data collection form. Table 2 indicates the results of the quality ratings. Each asterisk means one star, and the total scale of NOS is the summation of the stars (nine is the maximum), which are allocated for selection (four stars), comparability (two stars), and outcome (three stars).

\section{Data Synthesis}

Four extensive outcomes were considered: (1) medical cost; (2) drug cost; (3) healthcare utilization; and (4) others (facility revenue, drug revenue, and government subsidy). The baseline and intervention for the outcome variables were evaluated.

\section{RESULTS}

\section{Characteristics of the Included Studies}

As shown in Figure 1, our investigation started with 40 records after ruling out repeats. We discarded 25 records that could not fulfill the selection criteria. Fifteen studies (including 
TABLE 2 | Quality assessment of included studies using the Newcastle-Ottawa Scale (NOS).

\begin{tabular}{|c|c|c|c|c|c|c|c|c|c|}
\hline \multirow[t]{2}{*}{ Source } & \multicolumn{4}{|c|}{ Selection } & \multirow{2}{*}{$\begin{array}{c}\text { Comparability } \\
\text { (1) }\end{array}$} & \multicolumn{3}{|c|}{ Exposure } & \multirow[t]{2}{*}{ Total NOS score } \\
\hline & (1) & (2) & (3) & (4) & & (1) & (2) & (3) & \\
\hline Zhou et al. 2015 (5) & $\star$ & $\star$ & $\star$ & $\star$ & $\star \star$ & $\star$ & $\star$ & & 8 \\
\hline Zhou et al. 2015 (7) & $\star$ & $\star$ & $\star$ & $\star$ & $\star \star$ & $\star$ & $\star$ & & 8 \\
\hline Tian et al. 2016 (8) & & & $\star$ & & & $\star$ & & & 2 \\
\hline Wei et al. 2017 (9) & $\star$ & $\star$ & $\star$ & & $\star \star$ & $\star$ & & & 6 \\
\hline Yang et al. 2017 (2) & $\star$ & & $\star$ & & & $\star$ & & & 3 \\
\hline Fu et al. 2018 (10) & $\star$ & & $\star$ & & $\star \star$ & $\star$ & & & 5 \\
\hline He et al. 2018 (3) & $\star$ & & $\star$ & & & $\star$ & & & 3 \\
\hline Tang et al. 2018 (1) & & & $\star$ & & & $\star$ & & & 2 \\
\hline Yin et al. 2018 (11) & $\star$ & & $\star$ & & & $\star$ & & & 3 \\
\hline Mao et al. 2019 (12) & $\star$ & & $\star$ & & & $\star$ & & & 3 \\
\hline Shi et al. 2019 (13) & $\star$ & & $\star$ & & $\star \star$ & $\star$ & & & 5 \\
\hline Zeng et al. 2019 (4) & $\star$ & $\star$ & $\star$ & $\star$ & $\star$ & $\star$ & & & 6 \\
\hline Jiang et al. 2020 (14) & $\star$ & & $\star$ & & $\star \star$ & $\star$ & $\star$ & & 6 \\
\hline Li et al., 2021 (15) & $\star$ & & $\star$ & & $\star \star \star$ & $\star$ & & & 5 \\
\hline Du et al., 2021 (16) & $\star$ & & $\star$ & & $\star \star$ & $\star$ & & & 5 \\
\hline
\end{tabular}

\section{Selection}

(1) Representativeness of the exposed cohort.

(2) Selection of the non-exposed cohort.

(3) Ascertainment of exposure.

(4) Demonstration that outcome of interest was not present at start of study.

Comparability

(1) Comparability of cohorts on the basis of the design or analysis.

Exposure

(1) Assessment of outcome.

(2) Was follow-up long enough for outcomes to occur.

(3) Non-response rate.

retrospective cohort studies, time series studies, and quasiexperimental studies) were eventually included (1-5, 7-16). Table 3 outlines the features of the selected studies. All of the studies included were from China. Not all studies were classified as having more than seven stars based on the NOSs, and some were believed to be of lower quality. Table 3 also shows the various estimated results.

\section{Medical Cost}

The total expenses decreased by 3.12 and 65.6 U.S. dollars for outpatients and inpatients, respectively, per visit according to the quasi-experimental study design. The expense of each visit was predicted to show a decrease of $11 \%$ for both outpatient and inpatient medical services (5). One retrospective followup study showed that there was an increase in the annual number of patient visits (8). Another study revealed that there was a significant reduction in the expense of hospitalization per month (2). In addition, an increase in expenditure on clinical services was noted, while no alteration in overall healthcare costs was observed (10). The medication reform did not manage to longitudinally decrease the overall health expenditure of the patients (3). The great growth in the investment of the government in hospitals offsets the revenue from the sales of Western medicine, meaning that the zero-markup drug policy (ZMDP) can be considered a success; however, whether the investment of the government can last for a long duration is a factor that needs to be considered (13). A positive relationship was also found between the compensation for the situation of services and the contents of the annual income of clinical services (1). However, no meaningful modification of the average medical expenditure per treatment was noticed (12).

\section{Drug Cost}

One selected study revealed that not only the costs of drugs per patient visit declined by 4.47 U.S. dollars (outpatient services) or 45.75 U.S. dollars (inpatient services) but also the proportion of money spent on drugs out of the overall medical expenditure per patient visit decreased by $11.73 \%$ for outpatient visits and $3.92 \%$ for inpatient visits (5). Another study showed that the implementation of ZPED was associated with a reduction in the use of antibiotics (11). ZPED succeeded in removing the profits from Western medicines from the revenues of county hospitals without significantly disrupting their normal operation (17). In addition, the change in policy caused a reduction in drug expenditure (10). The medication reform was only able to decrease drug expenses in the short term (3). One study showed that the number of medicines prescribed per patient and the use of antibiotics, intramuscular injections, and intravenous injections reduced, while the use of hormones increased (12). The total drug expenditure decreased by $14.4 \%$, while the drug expenditure of outpatients with chronic diseases in tertiary 


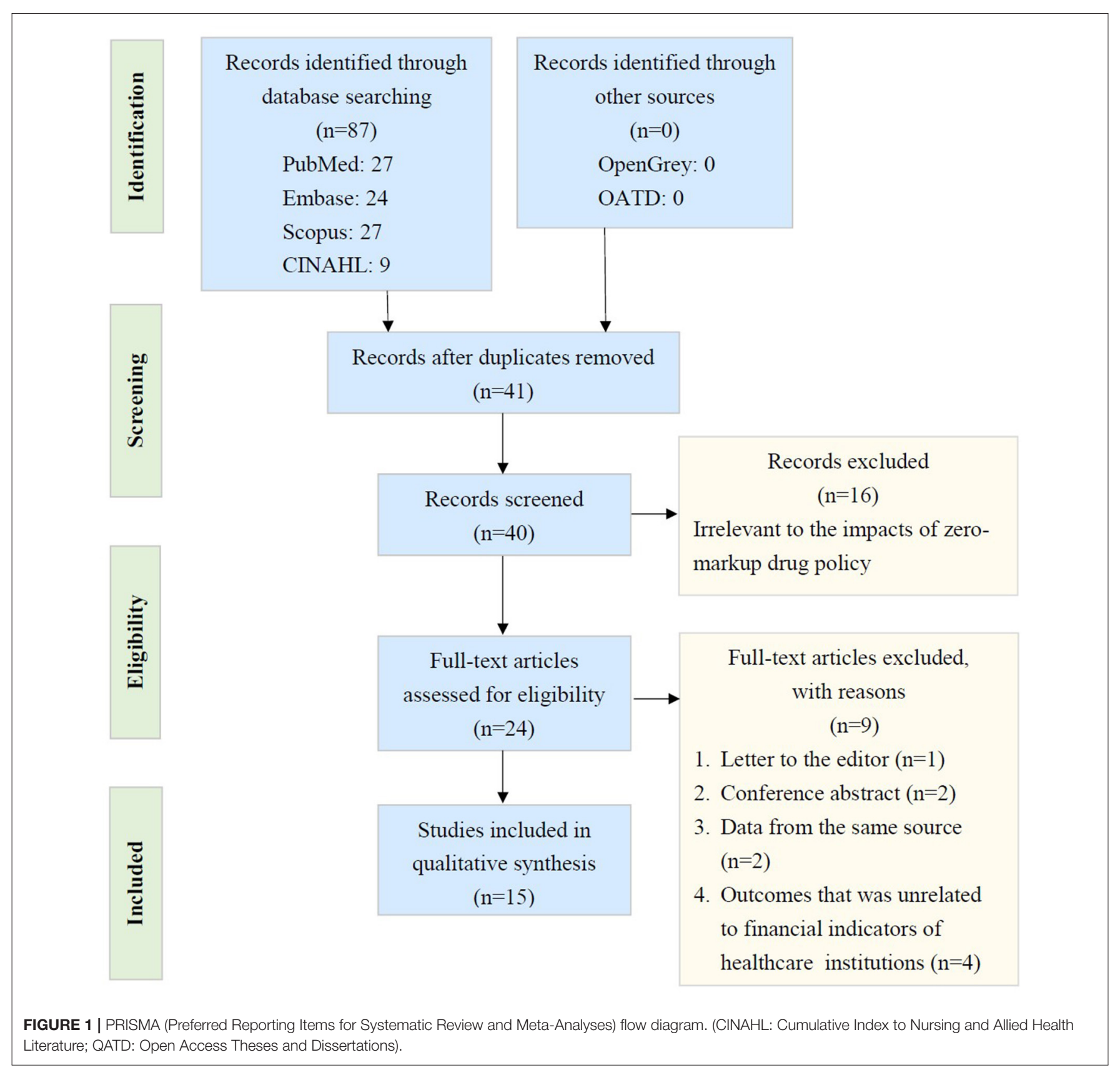

hospitals was reduced due to the implementation of the ZPED $(14,16)$.

\section{Healthcare Utilization}

With regard to the reduction in the ratio of medicine to healthcare charges in services to patients, both outpatient and inpatient services showed increases in the annual number of patient visits (8). ZPED may be associated with decreases in antibiotic prescriptions and intravenous infusions for outpatient visits (9).

The provision of outpatient services increased in the treatment group by $28.55 \%$, while the provision of inpatient services increased by $16.17 \%$. The provision of outpatient services was similar to that of the control group, and the provision of inpatient services only increased by $1.31 \%$. Following the implementation of a zero-markup policy, the provision of outpatient and inpatient services in the treatment group increased by 9,697 and 398 visits, respectively [27].

\section{Others}

The great reduction in expenditure on drugs caused more physicians to induce patients/healthcare service needs. The separation of hospital revenue from drug sales (SHRDS) policy is not an effective means of controlling healthcare expenditure 
(16). In addition, the increase in inpatient physician workdays decreased the mortality rate of inpatients. Workloads and inflation-adjusted per visit medical care charges of physicians increased in the outpatient services (8).

\section{DISCUSSION}

\section{Clinical Implications of a Zero-Markup Policy}

Few systematic reviews have been conducted to explore the effects of ZPED for essential drugs on healthcare costs and utilization in China. Based on the included studies, we showed that there were considerable decreases in both the drug cost and the total expenditure per patient visit. Medical services also revealed increasing levels of inpatient visits annually. In China, the economic benefit of prescribing medicines was most regularly referred to as a reason potentially causing the illogical use of medicines in a previous systematic review (18). However, the improvement of the reasonable use of medicines still has many unpredictable deficiencies. ZPED covers nationallevel medicines, while lower-level governments develop the list according to local requirements. The main effect of the medical policy is to avoid hospitals not only being seldomly sufficiently reimbursed but also from having to deal with financial embarrassments due to the complicated medical circumstances involved (19).

ZPED has been proven to decrease the medical costs of patients, leading to the reform of the inpatient and outpatient structures (20). Hospitalization does not depend on the cost of outpatient care (20); however, both outpatient medical care and inpatient medical care are determined by medical factors, such as the health status of patients. Outpatient care is a shortterm medical service that does not require an overnight stay in a hospital or a medical facility. Meanwhile, inpatient care involves continuous processes between patients and medical staff, in which the perception of the interaction of inpatients between the environment and service process is valued (21). Further studies should be conducted to explore the improvement of the medical care service system, the public health system, and the drug supply system. In addition, the results from the behavioral economic studies have indicated that people often make decisions according to not only absolute but also relative changes in price $(5,22)$. This manner is at the polytechnic of relative thinking theory, which shows that people are affected more by relative changes than absolute changes in a given initial stage (5).

In addition, the results of the selected studies concern the cost containment policy of healthcare, which changes prices for drugs and medical services. Changing prices is a broadly applied policy instrument in most Western countries (10). Rules and regulations of price alone would not yield a successful decrease in expenses because healthcare providers could avoid regulations by message merit. It is a fact that China experiences pressure regarding healthcare. Increasing the provisions of other medical services by increasing prices may compensate for the loss of revenue in most public hospitals in China (10).

\section{Clinical Practice of Zero-Markup Policy}

This systemic review showed that there has been a major improvement in drug costs and the number of patient visits in spite of there being some heterogeneity in terms of total expenses. According to these findings, medical teams should set up a customized agreement to manage or decrease medical expenses using ZPED due to the growth or reduction in healthcare costs primarily being dependent on hospital practices (23). For example, both outpatient and inpatient payments were reduced in health centers in towns but not in those of county status or above (8). The monitoring system should include a longitudinal evaluation with advanced and alternative approaches for the improvement of expenditure.

The zero-markup policy for essential drugs plays an important role in decreasing the cost of drugs for chronic noncommunicable diseases, such as type 2 diabetes, hypertension, metabolic syndrome, coronary heart disease, and cancer (21). In China, urban employees with basic medical insurance cannot afford outpatient expenses. Outpatient expenses could be deducted from the amount in the personal account, such as a partial return of the paid amount (16). A previous study also demonstrated that the abolishment of the drug markup fee at public hospitals has more predictable benefits for patients if they are urban employees with basic medical insurance (24). In addition, due to the limited reimbursement rate for patients who are urban residents with basic medical insurance, such patients may be more inclined to purchase drugs independently outside of the hospital, meaning that the execution of the ZPED in tertiary hospitals is less effective on medical costs. In contrast, urban employees with basic medical insurance may have a relatively higher awareness of reasonable drug use or may be more willing to make the decision to purchase drugs at hospitals (16).

\section{Methodological Considerations}

Several methodological perspectives should be addressed when applying the findings of this systematic review. First, the relatively small number of selected studies limits the power of our conclusions. Second, the included studies vary in terms of methodological quality, which may have introduced some risk of bias. Third, from a statistical viewpoint, it is worth using either qualitatively or statistically presented aggregated evidence; however, it would be difficult to conduct a meta-analysis of the selected studies because the included studies do not provide consistent information. Finally, the findings might not be able to be generalized to other medical institutions, as the studies we included were conducted in only a few areas of China. The external validity of our outcomes should also be further explored.

\section{Conclusions}

Although the government could implement ZEPD with the lower medical cost and drug cost to patients, and sustained income for health facilities, we have limited understanding of whether the increase in medical services was induced by the provider or was a response to unmet needs in the population. Further, studies using rigorous and advanced methods to study health policy, patient behaviors, provider behaviors, and government decisions are warranted. 
TABLE 3 | Characteristics of included studies in China.

\begin{tabular}{|c|c|c|c|c|c|c|c|}
\hline Author & $\begin{array}{l}\text { Publication } \\
\text { year }\end{array}$ & Study design & Area & $\begin{array}{l}\text { Hospital } \\
\text { accreditation }\end{array}$ & Outcomes & Statistical methods & Conclusions \\
\hline Zhou et al. (5) & 2015 & $\begin{array}{l}\text { Quasi-experimental } \\
\text { study }\end{array}$ & $\begin{array}{l}\text { Ningshan County, } \\
\text { Zhenping County, } \\
\text { and Shaanxi } \\
\text { Province }\end{array}$ & Secondary & $\begin{array}{l}\text { - Total expense per visit } \\
\text { (inpatient/outpatient service). } \\
\text { - Drug expense per } \\
\text { visit (inpatient/outpatient service). }\end{array}$ & $\begin{array}{l}\text { - Hospital-data } \\
\text { difference-in- } \\
\text { differences. } \\
\text { Individual-data } \\
\text { regressions. }\end{array}$ & $\begin{array}{l}\text { - The absolute monetary } \\
\text { reduction of the per-visit } \\
\text { inpatient expense is } 20 \text { times } \\
\text { of that in outpatient care. } \\
\text { - The relative reductions are } \\
\text { the same for outpatient and } \\
\text { inpatient visits. } \\
\text { - The incentive to utilize } \\
\text { outpatient or inpatient care } \\
\text { attributed to Zero-markup } \\
\text { Policy for Essential Drugs is } \\
\text { equivalent, regardless of the } \\
\text { price difference in } \\
\text { absolute terms. }\end{array}$ \\
\hline Zhou et al. (7) & 2015 & $\begin{array}{l}\text { Quasi-experimental } \\
\text { study }\end{array}$ & $\begin{array}{l}\text { Ningshan County } \\
\text { Hospital in Ankang } \\
\text { city, Shaanxi } \\
\text { province }\end{array}$ & & $\begin{array}{l}\text { - The effects of zero-markup } \\
\text { on medical expense } \\
\text { per visit. } \\
\text { - The effects of zero-markup } \\
\text { policy on medical } \\
\text { service provision. } \\
\text { - The effects of zero-markup } \\
\text { policy on the health care } \\
\text { revenue for hospitals. } \\
\text { - Estimates } \\
\text { of government subsidy. }\end{array}$ & $\begin{array}{l}\text { - A } \\
\text { difference-in-difference } \\
\text { model to measure the } \\
\text { difference in several } \\
\text { indicators between } \\
\text { two hospitals. }\end{array}$ & $\begin{array}{l}\text { With minimal or no subsidy, the } \\
\text { government can catalyze the } \\
\text { zero-markup policy and } \\
\text { potentially generate positive } \\
\text { outcomes for county hospitals. }\end{array}$ \\
\hline Tian et al. (8) & 2016 & $\begin{array}{l}\text { Descriptive study } \\
\text { (retrospective } \\
\text { longitudinal study) }\end{array}$ & Beijing & Tertiary & $\begin{array}{l}\text { - } \text { Annual patient-visits. } \\
\text { - Ratios of } \\
\text { medicine-to-healthcare- } \\
\text { charges (RMOH). } \\
\text { - Physician work-days } \\
\text { (inpatient/outpatient service). } \\
\text { - Physician-workload } \\
\text { (inpatient/outpatient service). } \\
\text { - Inflation-adjusted per-visit } \\
\text { healthcare charges } \\
\text { (inpatient/outpatient service). } \\
\text { - Mortality- } \\
\text { rate (inpatient/outpatient service). }\end{array}$ & $\begin{array}{l}\text { Rank-sum tests. } \\
\text { regression analyses. } \\
\text { roin-point } \\
\end{array}$ & $\begin{array}{l}\text { Implementation of Universal Zero- } \\
\text { Markup Drug Policy: } \\
\text { - Increase annual patient-visits } \\
\text { - Reduce RMOH } \\
\text { - Have different impacts on } \\
\text { outpatient and } \\
\text { inpatient services }\end{array}$ \\
\hline
\end{tabular}


TABLE 3 | Continued

\begin{tabular}{|c|c|c|c|c|c|c|c|}
\hline Author & $\begin{array}{l}\text { Publication } \\
\text { year }\end{array}$ & Study design & Area & $\begin{array}{l}\text { Hospital } \\
\text { accreditation }\end{array}$ & Outcomes & Statistical methods & Conclusions \\
\hline Wei et al. (9) & 2017 & Natural experiment & Guangxi & $\mathrm{N} / \mathrm{A}$ & $\begin{array}{l}\text { - Antibiotic prescribing rate } \\
\text { (outpatients with a primary } \\
\text { diagnosis of upper } \\
\text { respiratory tract infection). }\end{array}$ & $\begin{array}{l}\text { - Difference-in-difference } \\
\text { analyses. }\end{array}$ & $\begin{array}{l}\text { The national essential medicines } \\
\text { scheme and zero-mark-up policy } \\
\text { may be associated with } \\
\text { reductions in outpatient antibiotic } \\
\text { prescribing and intravenous } \\
\text { infusions. }\end{array}$ \\
\hline Yang et al. (2) & 2017 & Time series study & Shaanxi Province & Primary & $\begin{array}{l}\text { - } \text { Monthly average } \\
\text { hospitalization } \\
\text { expenditure (AHE). } \\
\text { - } \text { Monthly average } \\
\text { hospitalization expenditure } \\
\text { after reimbursement (AHER). }\end{array}$ & $\begin{array}{l}\text { - Segmented regression } \\
\text { analysis of interrupted } \\
\text { time series data. }\end{array}$ & $\begin{array}{l}\text { A statistically significant absolute } \\
\text { decrease in the level or trend of } \\
\text { monthly AHE and AHER was } \\
\text { detected after the introduction of } \\
\text { the zero-markup drug policy in } \\
\text { western China. However, } \\
\text { hospitalization expenditure and } \\
\text { hospitalization expenditure after } \\
\text { reimbursement were still } \\
\text { increasing. More effective } \\
\text { policies are needed to prevent } \\
\text { these costs from continuing to } \\
\text { rise. }\end{array}$ \\
\hline Fu et al. (10) & 2018 & Penal study & 1,880 counties & $\mathrm{N} / \mathrm{A}$ & $\begin{array}{l}\text { Outpatient care } \\
\text { - Total expenditures per visit. } \\
\text { - Drug expenditures per visit. } \\
\text { - Expenditures for diagnostic } \\
\text { tests/medical consumables } \\
\text { per visit. } \\
\text { - Expenditures for medical } \\
\text { services per visit. } \\
\text { - Outpatient visits. } \\
\text { Inpatient care } \\
\text { - Total expenditures } \\
\text { per admission. } \\
\text { - Drug expenditures } \\
\text { per admission. } \\
\text { - Expenditures for diagnostic } \\
\text { tests/medical consumables } \\
\text { per admission. } \\
\text { - Expenditures for medical } \\
\text { services per admission. } \\
\text { - Inpatient admissions. } \\
\text { - Average length } \\
\text { of inpatient stay. }\end{array}$ & $\begin{array}{l}\text { - Pre-trend test based on } \\
\text { linear regressions. }\end{array}$ & $\begin{array}{l}\text { The policy change led to a } \\
\text { reduction in drug expenditures, a } \\
\text { rise in expenditures for medical } \\
\text { services, and no measurable } \\
\text { changes in total health } \\
\text { expenditures. However, this } \\
\text { study also found an increase in } \\
\text { expenditures for diagnostic } \\
\text { tests/medical consumables at } \\
\text { hospitals that had a greater } \\
\text { reliance on drug revenues before } \\
\text { the reform, which is unintended } \\
\text { by policymakers. Further, these } \\
\text { results were more likely to be } \\
\text { driven by the supply side, } \\
\text { suggesting that hospitals offset } \\
\text { the reductions in drug revenues } \\
\text { by increasing the provision of } \\
\text { services and products with } \\
\text { higher price-cost margins. }\end{array}$ \\
\hline
\end{tabular}


TABLE 3 | Continued

\begin{tabular}{|c|c|c|c|c|c|c|c|}
\hline Author & $\begin{array}{l}\text { Publication } \\
\text { year }\end{array}$ & Study design & Area & $\begin{array}{l}\text { Hospital } \\
\text { accreditation }\end{array}$ & Outcomes & Statistical methods & Conclusions \\
\hline He et al. (3) & 2018 & Time series study & $\begin{array}{l}\text { Sanming City, Fujian } \\
\text { Province }\end{array}$ & $\begin{array}{l}\text { Secondary }(n=4) \\
\text { and tertiary } \\
(n=21)\end{array}$ & $\begin{array}{l}\text { - Outpatient } \\
\text { drug expenditure. } \\
\text { - Outpatient total } \\
\text { - } \text { nealth expenditure. } \\
\text { - Inpatient drug expenditure. } \\
\text { Inpatient } \\
\text { total health expenditure. }\end{array}$ & $\begin{array}{l}\text { - Interrupted time series } \\
\text { analysis with three } \\
\text { segments divided by } \\
\text { two intervention points. }\end{array}$ & $\begin{array}{l}\text { Although, the pharmaceutical } \\
\text { reform could control or reduced } \\
\text { drug expenditure and total health } \\
\text { expenditure in short term, } \\
\text { expenditures gradually resumed } \\
\text { growing again and reached or } \\
\text { even exceeded their baseline } \\
\text { levels of pre-reform period, } \\
\text { indicating the effect became } \\
\text { weakened or even faded out in } \\
\text { long term. }\end{array}$ \\
\hline Tang et al. (1) & 2018 & $N / A$ & $\begin{array}{l}\text { Nanjing City, Jiangsu } \\
\text { Province }\end{array}$ & $\begin{array}{l}\text { Secondary and } \\
\text { tertiary }\end{array}$ & $\begin{array}{l}\text { - The markup ratio of } \\
\text { drug sales. } \\
\text { - The growth rate of } \\
\text { medical service revenue. }\end{array}$ & $\begin{array}{l}\text { - Simple linear interrupted } \\
\text { time series regressions. }\end{array}$ & $\begin{array}{l}\text { Nanjing's pricing and } \\
\text { compensation reform has } \\
\text { basically achieved the policy } \\
\text { targets of eliminating the drug } \\
\text { markups, promoting the growth } \\
\text { of medical services revenue, and } \\
\text { adjusting the structure of medical } \\
\text { revenue. However, the growth } \\
\text { rate of service revenue of } \\
\text { hospitals varied significantly from } \\
\text { one another. }\end{array}$ \\
\hline Yin et al. (11) & 2018 & Time series study & Shandong Province & $\begin{array}{l}\text { Secondary tertiary, } \\
\text { and urban/rural } \\
\text { primary healthcare } \\
\text { centers (PHCs) }\end{array}$ & $\begin{array}{l}\text { - Total annual } \\
\text { antibiotic expenditure. } \\
\text { - Antibiotic expenditure per } \\
\text { person per year. }\end{array}$ & - Descriptive statistics. & $\begin{array}{l}\text { The overall antibiotic expenditure } \\
\text { increased over time in } \\
\text { Shandong, China. However, the } \\
\text { increase rate of expenditure } \\
\text { began to decline in } 2016 \text {, } \\
\text { possibly related to the } \\
\text { implementation of antibiotic } \\
\text { stewardship initiatives. }\end{array}$ \\
\hline
\end{tabular}

(Continued) 
TABLE 3 | Continued

\begin{tabular}{|c|c|c|c|c|c|c|c|}
\hline Author & $\begin{array}{l}\text { Publication } \\
\text { year }\end{array}$ & Study design & Area & $\begin{array}{l}\text { Hospital } \\
\text { accreditation }\end{array}$ & Outcomes & Statistical methods & Conclusions \\
\hline Mao et al. (12) & 2019 & Penal study & $\begin{array}{l}\text { Hangzhou City, } \\
\text { Zhejiang Province }\end{array}$ & $\begin{array}{l}\text { Primary }(n=6), \\
\text { secondary }(n=2), \\
\text { and tertiary }(n=9)\end{array}$ & $\begin{array}{l}\text { - Average number } \\
\text { of medicines. } \\
\text { - Average number } \\
\text { of antibiotics. } \\
\text { - Average } \\
\text { expenditure per prescription. }\end{array}$ & $\begin{array}{l}\text { - } T \text {-test. } \\
\text { - Pearson Chi-square } \\
\text { test or Fisher exact test. }\end{array}$ & $\begin{array}{l}\text { The average number of } \\
\text { medicines per prescription, use } \\
\text { of antibiotics, intramuscular (IM) } \\
\text { injections and intravenous (IV) } \\
\text { injections decreased while the } \\
\text { use of hormones increased. No } \\
\text { significant change of the average } \\
\text { medicine expenditure per } \\
\text { prescription was observed. The } \\
\text { problems of poly-pharmacy, } \\
\text { overuse of antibiotics, } \\
\text { intramuscular (IM) injections and } \\
\text { intravenous (IV) injections and } \\
\text { hormones still existed, however } \\
\text { mitigated after the } \\
\text { implementation of The National } \\
\text { Essential Medicine Policy and } \\
\text { the Zero Mark-up Policy. }\end{array}$ \\
\hline Shi et al. (13) & 2019 & Penal study & $\begin{array}{l}\text { All TCM county } \\
\text { hospitals }\end{array}$ & & $\begin{array}{l}\text { - Revenue from government } \\
\text { subsidies. } \\
\text { - Share of revenue from drug } \\
\text { sales (divide the amount of } \\
\text { revenue from TCM and } \\
\text { Western medicine by total } \\
\text { revenue except government } \\
\text { subsidies). } \\
\text { - Revenue from Chinese } \\
\text { medicine sales. } \\
\text { - Revenue from western } \\
\text { medicine sales. } \\
\text { - Revenue from medical care } \\
\text { services. } \\
\text { - Gross revenue. } \\
\text { - The number of annual } \\
\text { outpatient visits and the } \\
\text { number of } \\
\text { inpatient admissions. }\end{array}$ & - Difference-in-difference. & $\begin{array}{l}\text { - ZMDP achieved its stated } \\
\text { goal through reducing the } \\
\text { share of revenue from drug } \\
\text { sales without disrupting } \\
\text { the availability of healthcare } \\
\text { services at TCM county } \\
\text { hospitals no matter in the short } \\
\text { term or long term. } \\
\text { - The success of ZMDP was } \\
\text { mainly due to the huge growth } \\
\text { in the government's financial } \\
\text { investment in TCM hospitals, } \\
\text { which offset western medicine } \\
\text { sales revenue, while } \\
\text { maintaining current hospital } \\
\text { service levels. However, } \\
\text { whether government financial } \\
\text { investment can continue such } \\
\text { long-term growth remains an } \\
\text { open question. }\end{array}$ \\
\hline Zeng et al. (4) & 2019 & & Beijing City & $\begin{array}{l}\text { Urban employee } \\
\text { basic medical } \\
\text { insurance }\end{array}$ & $\begin{array}{l}\text { - The total expenditure and } \\
\text { other expenditure } \\
\text { components of } \\
\text { the pilot hospitals. }\end{array}$ & $\begin{array}{l}\text { - 1:1 propensity } \\
\text { score-matched analysis } \\
\text { (Propensity scores were } \\
\text { calculated by } \\
\text { logistic regression). }\end{array}$ & $\begin{array}{l}\text { After the zero markup drug } \\
\text { policy, expenditure on drugs } \\
\text { revealed a continuous decline. } \\
\text { However, the decline in total } \\
\text { expenditure was weakened by } \\
\text { the substitution effect of medical } \\
\text { consumables in the long term. }\end{array}$ \\
\hline
\end{tabular}


TABLE 3 | Continued

\begin{tabular}{|c|c|c|c|c|c|c|c|}
\hline Author & $\begin{array}{l}\text { Publication } \\
\text { year }\end{array}$ & Study design & Area & $\begin{array}{l}\text { Hospital } \\
\text { accreditation }\end{array}$ & Outcomes & Statistical methods & Conclusions \\
\hline Jiang et al. (14) & 2020 & Penal study & Shandong Province & $\begin{array}{l}\text { Secondary and } \\
\text { tertiary }\end{array}$ & $\begin{array}{l}\text { - Revenue from medicine } \\
\text { - Thes. } \\
\text { medicine sales. } \\
\text { - Evenue from medical care } \\
\text { services. } \\
\text { - Government subsidies. } \\
\text { - Revenue and expenditure } \\
\text { surplus. } \\
\text { - Gross revenue. } \\
\text { - The number of annual } \\
\text { outpatient and } \\
\text { inpatient visits. }\end{array}$ & $\begin{array}{l}\text { - Difference-in-difference } \\
\text { analyses. }\end{array}$ & $\begin{array}{l}\text { - The ZMDP achieved its some } \\
\text { initial goals of removing the } \\
\text { profits from western medicines } \\
\text { in county hospitals' revenue } \\
\text { without disrupting the normal } \\
\text { operation, and had different } \\
\text { impacts between county } \\
\text { general andTCM hospitals. } \\
\text { - Meanwhile, some unintended } \\
\text { consequences were also } \\
\text { recognized through the } \\
\text { analysis, such as the decline } \\
\text { of the utilization of the TCM. }\end{array}$ \\
\hline Li et al. (15) & 2021 & Penal study & Chengdu City & $\begin{array}{l}\text { Urban employee } \\
\text { basic medical } \\
\text { insurance }\end{array}$ & $\begin{array}{l}\text { - A series of expenditure } \\
\text { variables (actual } \\
\text { reimbursement expenditure, } \\
\text { reimbursement ratio, total } \\
\text { healthcare expenditures, } \\
\text { drug expenditure, } \\
\text { examinations expenditure, } \\
\text { material expenditure, } \\
\text { nursing expenditure, etc.). }\end{array}$ & $\begin{array}{l}\text { - Difference-in-difference } \\
\text { analyses. }\end{array}$ & $\begin{array}{l}\text { - After implementing the SHRDS } \\
\text { policy, the significant reduction } \\
\text { in drug expenditure led to } \\
\text { more physicians inducing } \\
\text { patients' healthcare service } \\
\text { needs, and the increased } \\
\text { social healthcare burden was } \\
\text { partially transferred to the } \\
\text { patients' personal economic } \\
\text { burden through the decline in } \\
\text { the reimbursement ratio. } \\
\text { - The SHRDS policy is not an } \\
\text { effective way to control } \\
\text { healthcare expenditure. }\end{array}$ \\
\hline Du et al. (16) & 2021 & $\begin{array}{l}\text { Interrupted time series } \\
\text { study }\end{array}$ & Chongqing City & Tertiary & $\begin{array}{l}\text { - Average drug cost } 11 \text { per } \\
\text { month for NCDs' } \\
\text { outpatients analyzed overall. }\end{array}$ & $\begin{array}{l}\text { - Interrupted time } \\
\text { series analysis. }\end{array}$ & $\begin{array}{l}\text { - The ITS analysis is an effective } \\
\text { method of health policy } \\
\text { evaluation. } \\
\text { - The implementation of the } \\
\text { ZMDP can reduce the drug } \\
\text { cost for chronic disease } \\
\text { outpatients in the tertiary } \\
\text { hospital and their economic } \\
\text { burden. } \\
\text { - Follow-up policies still require } \\
\text { targeted price adjustments in } \\
\text { the health service system to } \\
\text { adjust the drug cost effectively. }\end{array}$ \\
\hline
\end{tabular}




\section{DATA AVAILABILITY STATEMENT}

The raw data supporting the conclusions of this article will be made available by the authors, without undue reservation.

\section{AUTHOR CONTRIBUTIONS}

W-YL, C-HH, T-JL, P-EC, T-HT, and C-WC conducted the study and drafted the manuscript. W-YL, C-HH, BZ,

\section{REFERENCES}

1. Tang W, Xie J, Lu Y, Liu Q, Mallone D, Ma A. Effects on the medical revenue of comprehensive pricing reform in Chinese urban public hospitals after removing drug markups: case of Nanjing. J Med Econ. (2018) 21:32639. doi: 10.1080/13696998.2017.1405817

2. Yang C, Shen Q, Cai W, Zhu W, Li Z, Wu L, et al. Impact of the zeromarkup drug policy on hospitalisation expenditure in western rural China: an interrupted time series analysis. Trop Med Int Health. (2017) 22:1806. doi: $10.1111 / \mathrm{tmi} .12817$

3. He Y, Dou G, Huang Q, Zhang X, Ye Y, Qian M, et al. Does the leading pharmaceutical reform in China really solve the issue of overly expensive healthcare services? Evidence from an empirical study. PLoS ONE. (2018) 16 13:e190320. doi: 10.1371/journal.pone.0190320

4. Zeng J, Chen $\mathrm{X}, \mathrm{Fu} \mathrm{H}, \mathrm{Lu} \mathrm{M}$, Jian W. Short-term and long-term unintended impacts of a pilot reform on Beijing's zero markup drug policy: a propensity score-matched study. BMC Health Serv Res. (2019) 19:916. doi: 10.1186/s12913-019-4764-Z

5. Zhou Z, Su Y, Campbell B, Zhou Z, Gao J, Yu Q, et al. The financial impact of the 'zero-markup policy for essential drugs' on patients in county hospitals in western rural China. PLoS ONE. (2015) 10:e0121630. doi: 10.1371/journal.pone.0121630

6. Lo CK, Mertz D, Loeb M. Newcastle-Ottawa scale: comparing reviewers' to authors' assessments. BMC Med Res Methodol. (2014) 14:45. doi: 10.1186/1471-2288-14-45

7. Zhou Z, Su Y, Campbell B, Zhou Z, Gao J, Yu Q, et al. The impact of China's Zero-Markup Drug Policy on county hospital revenue and government subsidy levels. J Asian Public Policy. (2015) 8:10216. doi: 10.1080/17516234.2015.1005561

8. Tian W, Yuan J, Yang D, Zhang L. Descriptive analysis on the impacts of universal zero-markup drug policy on a Chinese Urban Tertiary Hospital. PLoS ONE. (2016) 11:e0162795. doi: 10.1371/journal.pone.0162795

9. Wei X, Yin J, Walley JD, Zhang Z, Hicks JP, Zhou Y, et al. Impact of China's essential medicines scheme and zero-mark-up policy on antibiotic prescriptions in county hospitals: a mixed methods study. Trop Med Int Health. (2017) 22:1166-74. doi: 10.1111/tmi.12922

10. Fu H, Li L, Yip W. Intended and unintended impacts of price changes for drugs and medical services: evidence from China. Soc Sci Med. (2018) 211:114-22. doi: 10.1016/j.socscimed.2018.06.007

11. Yin J, Li Q, Sun Q. Antibiotic consumption in Shandong Province, China: an analysis of provincial pharmaceutical centralized bidding procurement data at public healthcare institutions, 2012-16. J Antimicrob Chemother. (2018) 73:814-20. doi: 10.1093/jac/dkx469

12. Mao W, Huang Y, Chen W. An analysis on rational use and affordability of medicine after the implementation of National Essential Medicines Policy and Zero Mark-up Policy in Hangzhou, China. PLoS ONE. (2019) 14:e213638. doi: 10.1371/journal.pone.0213638

13. Shi X, Zhu D, Man X, Wang W, Zhu K, Nicholas S, et al. "The biggest reform to China's health system": did the zero-markup drug policy achieve its goal at traditional Chinese medicines county hospitals? Health Policy Plan. (2019) 34:483-91. doi: 10.1093/heapol/ czz053 and T-JL participated in the design of the study and performed data synthesis. P-EC, BZ, T-HT, and C-WC conceived the study and participated in its design and coordination. All of the authors read and approved the final manuscript.

\section{FUNDING}

This study was supported by the Taizhou Hospital of Zhejiang Province, Linhai, China (No 27).

14. Jiang $\mathrm{X}, \mathrm{He} \mathrm{P}$, Zhu D, Shi X, Meng Q. Different impacts of the zeromarkup drug policy on county general and traditional Chinese medicine hospitals: evidence from Shandong province, China. Int J Equity Health. (2020) 19:219. doi: 10.1186/s12939-020-01326-w

15. Li L, Yu Q. Does the separating of hospital revenue from drug sales reduce the burden on patients? Evidence from China. Int J Equity Health. (2021) 20:12. doi: 10.1186/s12939-020-01363-5

16. Du J, Xie J, Qian Y, Wu M, Huang W, Yin J, et al. Impact of China's zero mark-up drug policy on drug cost of NCDs' outpatients: an interrupted time series analysis. BMC Health Serv Res. (2021) 21:404. doi: 10.1186/s12913-021-06414-3

17. Lv Y, Xue C, Ge Y, Ye F, Liu X, Liu Y, et al. Analysis of factors influencing inpatient and outpatient satisfaction with the Chinese military health service. PLoS ONE. (2016) 11:e0151234. doi: 10.1371/journal.pone.01 51234

18. Mao W, Vu H, Xie Z, Chen W, Tang S. Systematic review on irrational use of medicines in China and Vietnam. PLoS ONE. (2015) 10:e0117710. doi: 10.1371/journal.pone.0117710

19. Mao W, Chen W. The Zero Mark-up Policy for essential medicines at primary level facilities, China case study. In: Xu K, editor. Improving Health System Efficiency, Health Systems Governance \& Financing. Geneva: World Health Organization (2015).

20. Zhou Z, Su Y, Gao J, Xu L, Zhang Y. New estimates of elasticity of demand for healthcare in rural China. Health Policy. (2011) 103:25565. doi: 10.1016/j.healthpol.2011.09.005

21. Arabyat RM, Nusair MB, Al-Azzam SI, Alzoubi KH. Analysis of prevalence, risk factors, and potential costs of unnecessary drug therapy in patients with chronic diseases at the outpatient setting. Expert Rev Pharmacoecon Outcomes Res. (2020) 20:125-32. doi: 10.1080/14737167.2019.16 12243

22. Azar OH. Relative Thinking Theory. Microeconomics 0504002. Munich: University Library of Munich (2005). doi: 10.2139/ssrn.7 01581

23. Wang J, Zhen J, Fan W, Zhang Q, Zhang G. Investigation and analysis of the effects of national essential drug system on medical expenses in different levels of medical Institutions. Chin Pharm. (2013) 23:2982-4. doi: 10.6039/j.issn.1001-0408.2012.32.03

24. Wang J. Research on the Influence of Zero-Profit Drugs Sales Policy to the Patient Personal Burden-in the TianJin BinHai New Area as an Example. Master: Hebei United University (2015).

Conflict of Interest: The authors declare that the research was conducted in the absence of any commercial or financial relationships that could be construed as a potential conflict of interest.

Copyright (c) $2021 \mathrm{Liu}, \mathrm{Hsu}$, Liu, Chen, Zheng, Chien and Tung. This is an openaccess article distributed under the terms of the Creative Commons Attribution License (CC BY). The use, distribution or reproduction in other forums is permitted, provided the original author(s) and the copyright owner(s) are credited and that the original publication in this journal is cited, in accordance with accepted academic practice. No use, distribution or reproduction is permitted which does not comply with these terms. 